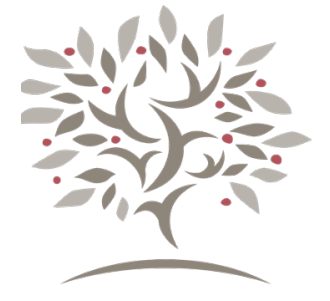

\title{
Can You Picture It? Curricular Imagination for the Transformative Art of Theological Education
}

\author{
Mai-Anh Le Tran \\ Garrett-Evangelical Theological Seminary
}

\begin{abstract}
A B S TRACT
This forum presents the written text (with added introduction) of remarks given at the installation of Mai-Anh Le Tran as academic dean at Garrett-Evangelical Theological Seminary. Naming the "colonial design" (Jennings) buttressing contemporary theological education, Tran wonders how the cultivation of educational imagination might invigorate a vibrant and vital place-based curriculum for theological discovery and formation that does not anesthetize, but rather awakens our full, unfinished selves for sense-filled meaning-making and "utopian social dreaming" for the transformative art of religious leadership in changing and challenging times.
\end{abstract}

\section{KEYWORDS}

theological education, colonial design, symbolic pedagogy, educational imagination, GarrettEvangelical, place-based curriculum, Isaiah 43, Psalm 23

\section{Concepts for A New Endeavor: A Framing Introduction (Or Afterword)}

"Modern theological education has always been inside the energy of colonial design. Colonial design is not one thing but many things organized around attention, affection, and resistance, each aiming, each navigating-each a design that designs" (Jennings 2020, 49). Synergized with the "aesthetic regime" (63) of white, Eurocentric, Christian vision, contemporary theological education as colonial design (and colonially designed) persists as an oft-concealed yet enduring inheritance that regulates who matters and what matters in the purposes of theological and religious teaching and learning. Whether on overt display or hidden in plain sight, this "bloody heirloom" (Coates 2017) claims transfixing monumental power within the theological habitation, "conjur[ing] a tailwind" for some beneficiaries, while communicating to others that they either do not really belong, or must prove their worth and legitimacy to remain (Anderson 2015).

The monumentality of colonial design, as piercingly depicted in Jennings's latest work, After Whiteness: An Education in Belonging, is not simply the implicit curriculum of theological education (when it is not the explicit curriculum, that is). It is a symbolic pedagogy, the undergirding principles, theories, and logics that organize 
valuations, decisions, and habits-a "paradigm" in the sense proposed by Thomas Kuhn: that "constitutive pattern according to which something is organized as a whole-in-parts"; "a normative model for a human endeavor or object of knowledge, the exemplar or privileged analogy that shows us what the object is like" (Green 1989, 52, 54). The ways in which this symbolic pedagogy designs within theological academic space are myriad: it frames assumptions about what is critical thinking, what is valued knowledge, what is "hard" versus "soft" disciplines and methodologies, what is rigorous scholarship; it choreographs the evaluation and assessment of competence, mastery, and success; it is the impulse compelling the selection of texts, materials, and experiences, and the selection of students, professors, administrators, and staff; it regulates modalities of and mechanisms for knowledge production, and dictates how learners are to be (re) positioned within milieus for learning, sometimes (en)forcing an estrangement from that which is familiar (and familial) to those who are "otherwise." Most painful of all, it authorizes levels of reward and impunity to those who make explicit display of their entitlement to this "bloody heirloom" (Coates 2017).

I have spent the last seventeen years as an academic striving in earnestness to learn about and to care for pedagogies, curricula, texts, evaluation and assessment, faculty development, educational innovation, and international partnerships for contemporizing and transnationalizing theological education. By habituation, I was transfixed by the monumental power that designed (and still designs) much of what I loved, for which I cared, and to which I devoted my life and career. While I might like to think that there has always been a streak of resistance in my formation and training and a defiant impulse in my own scholarly trajectory, as a "resident alien" who often feels "otherwise" in academic space, I find myself continuously overcome by the malignancy of this awful heirloom.

It was with such angst that I wrestled with the decision to accept the invitation to serve as vice president for academic affairs and academic dean of the seminary whose people I love and whose mission I believe in. What follows is a lightly "touched up" text of a frazzled dean's remarks at her installation service in February of 2020, an event that ended up occurring, after multiple rescheduling, at the most inopportune time for an over-extended small shop that had no clue that it would sit right at the center of the vortexes of global pandemic, social pain, climate crises, economic shortfalls, and internal implosions from frustrated hope. The texts for the service were Isaiah 43 and Psalm 23.

\section{Can You Picture It?}

Referring to the spiritual fervor of Eliza Garrett, founder of Garrett Biblical Institute (the first Methodist seminary established in the Midwest in 1853), professor of Early Christian Literature Charles Cosgrove wrote:

Eliza, like many earnest nineteenth-century women raised in Calvinist churches, was on a spiritual quest for signs that she was one of the elect. Presbyterians of her era required that those seeking church membership appear before the minister and church session and share personal experiences that testified to a true conversion. Eliza never felt confident that she had such proofs to share, and so, while she remained a faithful and active churchgoer, she did not become a member of any church until she attended a Methodist revival in Chicago, had an "experience," and was admitted to membership in First Methodist Episcopal Church. . . . Serious Methodists in her day prayed for "entire sanctification," and Eliza attended revivals in the hope of a "palpable" experience of this gift. It did not come. (2020)

It is not a stretch to say that every one of us spiritual types-and even those of us who don't identify as such-covets some palpable, emotional, even physical sign that, by God, we are the elect. Unfortunately for me, like Eliza, my sign has not come since I said “Okay, let's do it!” to President Lallene Rector in the spring of 2019. Oh, there have been many emotional states, all right. Surprise, bewilderment, befuddlement, apoplexy, fatigue, and, of course, due measures of joy and exhilaration, but not yet a "palpable" moment in which I experience "blessed assurance" that I am "entirely sanctified" to step into the role and take on the work with which I have been entrusted.

Perhaps part of it is the recognition of what historian George Mooar wrote back in the 186os: that "[i]t required a courage bordering on rashness to venture on a Theological Seminary" $(1894,6)$. It takes a courage bordering on rashness to invest

98 2021; 2:1 97-102 The Wabash Center Journal on Teaching

This work is licensed under a Creative Commons Attribution-NonCommercial 4.0 International License 
oneself in the enterprise of preparing religious leaders- "religious professionals," some call them now-whose primary function within wider society, whose expected contribution to the national culture and global conversation, is that of “interpreting God."

By this, theologians and researchers of seminary education mean that the religious professional as leader apprentices themselves into a "transformative art"-an art that excavates inherited and unknown archives and repertoires of faith knowledge and faith traditions, and transforms them into not just tools and tricks, but rather "'strategies' of 'new engagement" in the face of new situations, new challenges, new circumstances (Foster 2006, 23). This type of "engaging, integrating, and adapting learning" is not "skill training." Rather, it is an acute honing of our "way of seeing into and interpreting the world" (22)-a way of knowing, of being, and of making faith knowledge and faith experience palpable in our everyday sense-filled meaning-making.

In other words, one could say that we are in the business of cultivating imagination-religious, theological, ministerial, ecclesiastical, social-cultural imagination.

Now, when I am coloring with my seven-year-old niece, Amanda, imagination oozes out of her fingertips as she reaches for her acrylic paint and canvases, and pictures worlds in which unicorns, Squishies, Shopkins, and humans blissfully coexist!

But let us not be mistaken: imagination is not pie-in-the-sky make-believe or fantasy-filled voyeurism. (In fact, Amanda could tell you what's make-believe and what's not.) Rather, imagination is the capacity to picture-to image-the world beyond what is palpable to our human senses, to picture an "existence possibility" of something that defies the logics of our rational-deductive reasoning, and yet is firmly grounded in our deep, material attunement to what we know the world to be, as it presently is.

A fertile imagination recognizes what the late Brazilian education reformer Paulo Freire wrote: "The world [and we who are human parts of it] is not finished. It is always in the process of becoming" $(1998,72)$. And as a transformative art, imagination is not theory, but theory-laden, theory-in-the-making praxis-what religious educator Maria Harris described as "a set of bodily actions" that give flesh to hope $(1996,14)$, so that we may, in the words of Ghanaian Methodist theologian Mercy Amba Oduyoye, “wear hope like a skin” (Grey 2001, np).

This kind of imagination is not first-world ennui or privileged daydreaming-or, dare I say, not even "entrepreneurial innovation," in which we recycle ideas like you would go through some affluent rummage sale (à la Phyllis Tickle [2008]). Rather, it is about survival. One can see it instantiated by those who face dystopia, displacement, and debasement, whose backs are against the walls (Thurman 1996), who know too well what it means to not be able to "rest on the memories of your glorious past" or "lean on the certitude of your prior knowledge" (Isaiah 43:18). Theologically speaking, it is a "way of seeing into" and a "way of being" in the world that looks at the depths of evil and suffering, and asks, What on earth might God be doing in the midst of this?

Now, here is the tricky thing-and I'm bracing myself for the glares from faculty and our Associate Dean of Assessment: The cultivation of this kind of theological and religious imagination requires a robust curriculum that-wait for it-defies "onesize-fits-all" learning, standardized outcomes, and mechanized assessment. To be clear: Our faculty (and even students) know that I am a staunch proponent of robust learning benchmarks, outcomes, and assessment. That is not the problem. The trouble is if the honing of vibrant theological imagination is not buttressed by a robust educational imagination, in which we are able to picture that the curriculum of a seminary is more than what is taught in our classrooms-more than the syllabi, the lectures, the accumulation of credit hours and letter grades, though all of that is a good part of it.

Rather, Garrett's “curriculum” is the entire course of this seminary's life, the vibrant biodiversity of our community, the fecundity of our broad-ranging ecology that scaffolds multiple ways of discovery, the theo-ethical principles that frame our 
culture and guide our policies, the interpersonal commitments that choreograph our daily habits, and even the manuals that serve as guard rails in the event we lose our bearings. Garrett's curriculum is all of that-the explicit, the implicit, and even what's left out... because we know that what's not there teaches us as much as, if not more than, what is there.

For those of you who might be palpitating because you think the new dean is itching for curriculum revision, let your heart be at ease. Read my lips: No new curriculum revision! Instead, I mean curricular imagination: we live into the curriculum that we already are.

Dare we picture that the curriculum of Garrett-Evangelical Theological Seminary is place-based-it is rooted deeply in the terroir that we are in, the histories, legacies, peoples and memories, wisdom and technologies, past-present-future, both known and unknown to us. Remember-that which is unknown to us is very well known and named to others. ${ }^{1}$

Dare we imagine that the place-based curriculum at Garrett doesn't lean on the former regimes of our knowing, doing, and being-that it doesn't assume that it is good enough to be hospitable to the guests who come into our own house ... as long as it remains "our" house. Instead, we run the course with the assumption that we are all guests in one another's worlds, and that learning begins with a curiosity about what is beyond us, and deepens with a critical awareness of our own unfinishedness.

Dare we picture that the place-based curriculum at Garrett assumes that a course is more than a class-a course is that which transports us into worlds we didn't know existed. A course is a "boundary event" that compels us into messy, gritty, skin-to-skin contact with those "other" to us . . . be they in contexts of our "cross-cultural immersion" experiences like Palestine, China, Ghana, Rome, or the fifth ward of Evanston, a neighborhood house of worship seemingly foreign to us, or somebody a few seats away from us, or somebody several offices down the hall from us.

In these instances, it is not enough to strive for competence in knowing the other-because one could just as easily master knowledge of the other in order to destroy them. The place-based curriculum at Garrett teaches us that "my salvation is entangled with yours," so let us learn together.

Dare we picture that the place-based curriculum at Garrett assumes that we are products of a broken world-we come to learn as we are, fully, wholly, holy, broken. For some of us, it is a world that is designed against our success, such that even before we come through the doors of a school, we have already been tracked for failure. Willie Jennings calls it a pervasive “diseased imagination" (2010); Emilie Townes calls it “fantastic hegemonic imagination” (2016); Henry Giroux calls it straight-up disimagination (2014).

Against such disimagination, dare we perceive a place-based curriculum that pays attention to how the traumas of personal, social, cultural, and religious violence are scored, seared deeply in our bodies and our psyche. Dare we perceive a curriculum that attends to the toll of learning in the way that religious educator Maria Harris once described: learning with "all the faculties of human beings, all our resources, not only our seeing and hearing and touching, but also our history, our education, our feelings, our wishes, our love, hate, faith, and unfaith" $(1987,9)$. In other words, a place-based curriculum at Garrett that doesn't anesthetize, but rather awakens our bodily capacities to sense our way through God's world.

Finally, dare we picture that the place-based curriculum at Garrett forms and fashions us for what biblical scholars call "utopian social dreaming" (Tran 2017, 115), an insistence that the kin(g)dom of God can be materialized here on this earth, and that we are invited to participate in a life-long and life-wide course of divine instruction?

In this curriculum made for utopian social dreaming, we are taught-formed and fashioned-by God, as we accompany one another toward a "renewal of moral conscience, restoration of communal agency, reconstruction of critical analysis, resilience in self-reflective dialogue, and reconciliation through passionate [and compassionate] action” (Tran 2017, 139).

1 The stained glasses in the windows of our Chapel of the Unnamed Faithful depict images of those who are very well named and known in other worlds.

100 2021; 2:1 97-102 The Wabash Center Journal on Teaching

This work is licensed under a Creative Commons Attribution-NonCommercial 4.0 International License 
In the last few minutes, I have been referring to Garrett's place-based curriculum as though it is already here, even though we might very well be in the already-but-not-yet. Wearing hope like breathable, permeable skin, we recall that Second Isaiah implores, "Don't you perceive it? Can't you picture / image it? Is there capacity within your sense-filled meaningmaking to recognize that God is already doing new things in your midst?"

Let me close with an indulgent turn to the personal, to share with you how I witnessed this "perceptual capaciousness" in my late paternal grandmother. "Ô” was her name, Huỳnh Thị Ô-a single letter, like the number zero, so hollow it holds the universe. Grandma Ô was what you might describe as preliterate. She could barely read, but the banana stall that she kept in the town's wet market in Vietnam was the entrepreneurial ingenuity that fed four generations of hungry mouths in a household. In her old age, this life-long pious woman probably couldn't tell you if she had experienced any palpable signs of her entire sanctification. And yet, Grandma Ô could be heard chanting Psalm 23-couldn't carry the tune, but she'd chant the words as though it were a part of the systole and diastole of her beating heart. (We can call that "curricular rhythm," can't we?)

\section{Đức Giê-hô-va là Đấng chăn giữ tôi, tôi sẽ chẳng thiếu thốn gì . . .}

The Lord is my shepherd, I shall not want.

It was no warm-fuzzy "God and me” ballad. Psalm 23 was for her then, as it is for us now, a song of utopian social dreaming:

God is our shepherd, not unjust earthly rulers who would deny us clean water and green pastures ... In the deep shadows of our mortality, God is intimately there ... In the face of life-denying threats, God abides as host ... . Goodness and mercy will pursue us, rather than being ever beyond our grasp . ... And in God we find our dwellingour place is in God's world.

So, dear members and friends of Garrett-Evangelical Theological Seminary: We do not cling to former things, or consider the things of old .... For the curriculum that we are currently running is new and will always be new because God is our Teacher, the world is our classroom, the transformative art that we are apprenticing ourselves into is that of interpreting God within changing and challenging times. And the purpose of our endeavor-the why of this course which we run-is the conviction that we have been called (through our baptism): to "share in Christ's ministry of love and service ... to resist evil, injustice, and oppression, wherever and in whatever forms they present themselves ... for the redemption, renewal, and restoration of the human family and the whole of creation."

Can you picture it?!

\section{B I B LIOGRAPHY}

Anderson, Elijah. 2015. “The White Space." Sociology of Race and Ethnicity 1 (1): 10-21. https://sociology.yale.edu/ sites/default/files/pages from sre-11 rev5 printer files.pdf.

Coates, Ta-Nehisi. 2017. “The First White President.” The Atlantic, October 2017. https://www.theatlantic.com/ magazine/archive/2017/10/the-first-white-president-ta-nehisi-coates/537909/.

Cosgrove, Charles. 2020. “Eliza Clark Garrett (1805-1855), Founder of Garrett Biblical Institute.” The Styberg Library. https://library.garrett.edu/collections/special-collections/womens-history-digital-exhibit/eliza-clarkgarrett-1805-1855. 
Foster, Charles R. 2006. Educating Clergy: Teaching Practices and Pastoral Imagination. San Francisco, CA: JosseyBass.

Freire, Paulo. 1998. Pedagogy of Freedom: Ethics, Democracy, and Civic Courage. Lanham, MD: Rowman and Littlefield.

Giroux, Henry A. 2014. The Violence of Organized Forgetting: Thinking Beyond America's Disimagination Machine. San Francisco, CA: City Lights Books.

Green, Garrett. 1989. Imagining God: Theology and the Religious Imagination. 1st ed. San Francisco, CA: Harper and Row.

Grey, Mary C. 2001. The Outrageous Pursuit of Hope: Prophetic Dreams for the Twenty-first Century. New York, NY: Crossroad Pub.

Harris, Maria. 1987. Teaching and Religious Imagination. San Francisco, CA: Harper and Row.

Harris, Maria. 1996. Proclaim Jubilee: A Spirituality for the Twenty-first Century. Louisville, KY: Westminster John Knox.

Jennings, Willie James. 2020. After Whiteness: An Education in Belonging. Grand Rapids, MI: William B. Eerdmans Publishing Company.

Jennings, Willie James. 2010. The Christian Imagination: Theology and the Origins of Race. New Haven, CT: Yale University Press.

Mooar, George. 1894. “The Seminary of 1869-94." Quarter-Centennial Addresses.

Thurman, Howard. 1996. Jesus and the Disinherited. Boston, MA: Beacon Press.

Tickle, Phyllis. 2008. The Great Emergence. Grand Rapids, MI: Baker Books.

Townes, Emilie M. 2016. “Teaching and the Imagination.” Religious Education 111, no. 4: 366-79. https://doi.org/10.1 080/00344087.2016.1191586.

Tran, Mai-Anh Le. 2017. Reset the Heart: Unlearning Violence, Relearning Hope. Nashville, TN: Abingdon.

\section{ABOUT THE AUTHOR}

Mai-Anh Le Tran is Vice President for Academic Affairs and Academic Dean, and Associate Professor of Religious Education and Practical Theology at Garrett-Evangelical Theological Seminary, Evanston, IL. 